\title{
Employee Engagement in A Remote Working Scenario
}

\author{
Anoor Ashwini Anand, Sheetal N. Acharya \\ Departement of Management, Surana College, Bangalore University \# 16, South End Road, Bangalore - 560 004, India
}

\begin{tabular}{l} 
A R T I C L E I N F O \\
\hline Keywords: \\
Remote worker \\
Employee Engagement \\
Practice \\
Productivity \\
Crisis \\
Kata kunci: \\
Pekerja jarak jauh, \\
Keterikatan karyawan, \\
Praktik, \\
Produktivitas, \\
Krisis
\end{tabular}

Corresponding author: anoorashwini@gmail.com

\section{A B S T R A C T}

Remote working is a concept in which the employees do not commute or travel to the Organizations place of work but allows the employees to work outside of the traditional office environment. Employee engagement can be viewed as an attitude of an employee/employee's a to be productive, to excel and therefore be committed towards the organisation. Remote working applies to a variety of employees especially office or desk-based workers. This paper explores different facets of the remote worker's persona and provides recommendations and practices to enhance employee engagement of the employees working remotely. Remote work culture is not a new concept, but due to the current Covid-19 Pandemic situation there seems to be a rapid shift of many employees to the remote working model essentially working away from the traditional office ecosystem. This paper examines two aspects of working remotely, a. In regular times b. during a crisis and in both these scenarios how to keep the remote workers engaged and motivated to ensure a minimum if not zero loss of Productivity.

\section{SARI PATI}

Kerja jarak jauh adalah konsep di mana karyawan tidak bepergian atau bepergian ke tempat kerja di organisasi tetapi memungkinkan karyawan untuk bekerja di luar lingkungan kantor tradisional. Keterikatan karyawan dapat dilihat sebagai sikap karyawan untuk menjadi produktif, berprestasi dan karenanya berkomitmen terhadap organisasi. Kerja jarak jauh berlaku untuk berbagai karyawan terutama pekerja kantor atau meja. Makalah ini mengeksplorasi berbagai aspek kepribadian pekerja jarak jauh dan memberikan rekomendasi serta praktik untuk meningkatkan keterlibatan karyawan dari karyawan yang bekerja dari jarak jauh. Budaya kerja jarak jauh bukanlah konsep baru, tetapi karena situasi Pandemi Covid-19 saat ini, tampaknya ada pergeseran cepat banyak karyawan ke model kerja jarak jauh yang pada dasarnya bekerja jauh dari ekosistem kantor tradisional. Makalah ini membahas dua aspek dari bekerja dari jarak jauh, a. Pada waktu yang teratur b. selama krisis dan dalam kedua skenario ini bagaimana menjaga agar pekerja jarak jauh tetap terlibat dan termotivasi untuk memastikan hilangnya Produktivitas seminimal mungkin atau bahkan nol.

(C) 2021 IRJBS, All rights reserved. 


\section{INTRODUCTION}

Remote working: This concept of remote working focuses on working productively in a specific place outside the geographical location of the organization's principal or subsidiary facility, it is considered as a work arrangement outside of the office to be more precise. Remote working is not a new concept, though not very well accepted initially but with the advent of technology which has helped to successfully bridge the gap between the physical and digital world. Remote working or working from home has become a practical and preferred way of working in today's Covid-19 scenario where the safety of the employees is the paramount. Working remotely is mutually beneficial to both the employers and employees since it invariably helps reduce facility costs for the employer, maintain work-life balance for the employee, improve overall work output productivity whilst achieving organisational as well as personal goals. The future for working remotely as a work pattern looks very promising as various studies hitherto have suggested that a staggering seventy percent of the professionals will be working remotely by the year 2025. Keeping the employees engaged and motivated is key to success of working remotely, therefore this paper focuses on the various practices of employee engagement when working remotely.

Employee Engagement: "When people are financially invested, they want a return. When people are emotionally invested, they want to contribute." -This famous quote given by Simon Sinek explains that if the employees are engaged, they are likely to invest in the work they do which leads to higher quality of work. Employee engagement is a positive approach the employee has towards his work together with commitment towards organisational goals and values. Employee engagement is built on trust and Integrity through effective communication and commitment between the employer and the employees. Various studies on employee engagement have proven that Employee engagement is the mental and emotional connection the employees feel toward their place of work which when available results in increased loyalty, satisfaction thereby leading to a highly productive contribution to the success of the organisation. Working remotely being the choice of working environment in today's Covid-19 crisis, employee engagement plays a vital role in boosting the morale of the employees through effective communication and constant support for the wellbeing of the employee, employer, and organisation as a whole.

\section{METHODS}

\section{Research Framework}

The main purpose of the paper is to give direction and guidelines through its suggestive framework for employee engagement primarily focussing on employees working remotely. It may also act as a tool to the human resource managers in the time of uncertainties or crisis very similar to the current Covid-19 pandemic situation. The suggestive framework proposed in this paper has been developed through a systematic study of the existing Secondary literature on this paper's subject and/or closely related to the subjects around it. Additionally, a Survey tool was deployed to seek inputs from People Officers of Organizations (Sample set) to understand the techniques currently that have been deployed and its effectiveness.

\section{Research Gap}

Remote working or work from home as a preferred choice during a crisis similar to the current Covid-19 situation would potentially emerge as a longer-term strategic option for employers. Keeping the employees motivated and focused in the remote working situation is definitely a challenge for every organisation that needs to be focussed upon and addressed.

A set of practices that would positively influence the Employee engagement to help Organizations maintain the best level of engagement to achieve their Organization goals.

\section{Objectives}

1. To view the Remote working ecosystem vis-avis the Employee Engagement Paradigm 
2. To analyse the existing Employee engagement practices in Organisations which support and utilize the Remote working Model and propose a set of Definitive guidelines.

\section{Research Design:}

\section{Sources of data}

This paper is based on information collected through secondary data and primary data. Present Secondary data constructs to draw analysis and inference for the correlation between remote working and employee engagement parameters. The secondary data derived during the course of investigation is from various research articles, blogs, journals and online newspaper articles which has helped in providing insight into the importance of employee engagement while in a remote working model.

The industry input through experts plays a vital role in understanding the current practices of employee engagement working remotely, therefore the primary data was collected through a Survey tool designed for the purpose of this Paper which details the current Engagement practises in Organizations which support and utilize the Remote working model.

\section{Review of Literature}

Nisha Chanana and Sangeeta (2020) the researchers have tried to study the various employee engagement practices that were implemented during the pandemic. The researcher has tried to bring out the list of virtual employee engagement practices which helps in boosting the morale of the employees. The research is based on secondary data and is considered as a Conceptual paper. The researcher has found how virtual employee engagement keeps the employees motivated and increases the level of accountability towards work.

Dr Sachi Yadav, Anshuman Dubey, Pulkit, Saurav (2020) researchers of JNU have explored the employee engagement strategies in today's virtual environment with reference to the IT industry. The researchers in this paper have analysed the various aspects that have an impact in keeping the employees engaged. The researchers have explored the primary and secondary data for the identification of different parameters following with the thematic analysis of the data through Delphi Technique. It was observed by the researchers that it is a very difficult task to keep the employees engaged virtually and at the same time how effective communication plays a crucial role in engaging them productively.

Bhavani SA, Shravan, Arpitha (2015) the researchers have tried to understand the factors that influence the effectiveness of employee engagement. The researcher has utilized a random sampling method by conducting a survey with the help of a structured questionnaire. The researcher found that most of the employees were satisfied and had a sense of personal accomplishment. The researcher concluded that the employee's engagement plays a vital role as it helps in finding the level of satisfaction of employees at the workplace because happy employees are productive employees.

Anoop Kumar and Dr Shikha Kapoor (2020) the researchers have attempted to study the impact of two factors i.e., the emotional wellbeing and the use of digital platforms in employee engagement during the pandemic situation. The researchers have collected information using random sampling method through self-administered questionnaire given to employees working in major sectors of India engaged in essential services during lockdown. The researchers have concluded in this paper that if the employer is able to effectively evaluate the current emotional pattern of their employees with empathy, it can help them plan and respond in a mindful and healthier way.

Dr Beena Salim Saji (2014), the researcher focuses on the importance of building employee capabilities and employee engagement which helps in transforming the employee into the most reliable resource in a crisis. The researcher has attempted to understand the value of employee engagement during a crisis. The researcher has built a model 
based on employee engagement that can facilitate effective crisis management for organisations with a help of case study method - of Taj Hotel Mumbai during the terrorist attack.

Jayant Gaurav (2020), the researcher has tried to explain how to draw the employees closer during the times of Social Distancing. The researcher aims to put an idea forward through a suggestive framework of employee engagement to work from home during the pandemic situation. In this article the researcher has tried to make an appeal to the HR managers on how they should become a facilitator rather than an administrator to intrinsically draw the employees towards active participation than being obliged to do the work.

\section{Employee Engagement In Remote Working Scenario}

In Regular times: Remote workers remain socially connected to their home office through their email, instant messenger chat features or the occasional phone call from a supervisor or colleague. These digital means of connecting is augmented with a visit to the physical office at a predetermined frequency to enable establishing and enhancing the engagement quotient with the Physical office colleagues of the employee who is a remote worker.

During Crisis: The Pandemic has transformed the work ecosystem, where the employees' work practices were disrupted and a sudden transition to adapt to the remote working model as against the pre-pandemic Physical office working Model. Despite the hardships and sudden change, statistics have proved that there was an increase in the level of employee engagement from both the employer and the employees' mindfulness (as per the report of Reports of Gallup.com, 2020).

According to Nisha Chanana \& Sangeeta (2020) conceptual framework study they have put forth how technology has played a vital role in improved employee engagement and has brought an impactful growth of the organisation. They have provided an exhaustive list of tech-based employee engagement practices like

a. Virtual team meet - ups.

b. Webinars

c. Online sharing of best practices to maintain health and hygiene.

d. Digital classroom training

to name a few that will help in boosting the morale of the employees and make them more committed towards organisations in this crisis situation. Referring to the study by Anoop Kumar, Dr Shikha Kapoor (2020) where they have discussed the impact of two key factors, emotional wellbeing of the employees and the use of new digital platforms on employee engagement during the pandemic situation. The authors have proposed a model of five effective ways to enhance employee engagement -

- Personal connect.

- $\quad$ Listen \& educate employees.

- Health advisories

- Digital Platforms

- Wellbeing engagement

As per the study of Dr Shachi Yadav, Anshuman Dubey, Pulkit Chawla and Saurav Jha (2020) engaging the employees in a virtual environment is an arduous task as the employees miss team interactions, team gatherings, reduced employee development opportunities, work has become more monotonous, boring, and non-creative. They have emphasised the fact that, to make the virtual working concept more workable and engaging the employees must improve their soft skills as effective communication has a vital role in bringing positive outcomes in the crisis situation. Jayant Gaurav (2020) has revealed a suggestive framework to keep the employees engaged during lockdown under the Covid-19 pandemic situation. The two broad frameworks have been given by the author are.

1. integration framework which is designed as a tool to the HR manager which has a set of employee engagement activities that can be established through online platforms like WhatsApp, text messaging, tele calling and video calling. 
2. The second framework is for the IR/ER managers at plant locations where they can have personal contact with the workmen, try to understand their problems and arrange food supplies, monetary help and arrangement of other necessaries through crowdfunding. In this framework the researcher has suggested that the IR/ER managers display leadership traits where they can guide the workmen towards light in tough situations when the workmen are helpless and most vulnerable.

The author has put a strong message to all the managers and the leaders that they have to be empathetic towards their employees and play a role of facilitator rather than administrator. Dr Abha.R. Dixit \& Shobha Singh (2020) have focused their article on three main drives leadership, Communication and Meaningful purpose has helped in the employees engaged. The researcher has further divided the drives into intrinsic and extrinsic factors. Intrinsic drives are those where an employee finds meaningfulness in what he/ she is doing. The extrinsic drives of employee engagement like organisation supportiveness, work life balance, monetary benefits, recognitions, team orientation, career growth management, employee relations are the key drives for employee engagement. Researcher Beena Salim Saji (2020) has drawn attention towards building efficient and loyal staff that become a building block that can save companies during crises. The researcher has built an employee engagement model taken into consideration the best practices implemented at Taj Hotels, after analysing a case study where the employees of Taj Hotel, Mumbai showed exemplary courage and presence of mind while rescuing the guests during the terrorist attack. Such was their commitment and loyalty towards the organisation that they did not hesitate to risk or sacrifice their life for the safety of the guests. The model has taken into consideration the selection strategy of identifying the person with value towards respect and service towards the organisation, creating a supportive-trustful management culture, rewards and recognition from immediate managers, innovative reward schemes, training for selfefficacy and empowerment of all these factors, build psychological meaningfulness that transforms the employees into powerful resources which can handle crisis. A newspaper article in economic times by an HR expert has come up with a few employee engagements practices that can be followed in the changed working scenario like

- $\quad$ to digitally equip the employees

- $\quad$ support critical business operations.

- being more understanding and supportive towards the employees

- coaching the managers on trust quotient

- invest time to develop employee-employee relations.

In a blog by Deloitte (Ariana Roy Kewalramani) has given three recommendations on improving employee engagement in the changed work scenario,

- first one is the supportive role the management will play.

- second is to create a positive work environment.

- the third is to encourage trust in leadership..

\section{RESULT AND DICUSSIONS}

\section{Sampling}

Questionnaire was administered via sharing the google form to HR/People managers of various organisations. Total of 27 responses were received and used for data analysis.

\section{Data Analysis And Interpretation}

Table 1. showing results of the survey showing percentage of employees working remotely.

Table 1. Percentage of employees working remotely.

\begin{tabular}{ll}
\hline \multicolumn{1}{c}{ PARTICULARS } & PERCENTAGE \\
\hline $\begin{array}{l}100 \% \text { Employees working } \\
\text { remotely }\end{array}$ & $44.4 \%$ \\
\hline $\begin{array}{l}50-100 \% \text { Employees working } \\
\text { remotely }\end{array}$ & $55.6 \%$ \\
\hline \multicolumn{1}{c}{ Tess than 25\% } & 0 \\
\hline \multicolumn{1}{c}{ TOTAL } & $100 \%$ \\
\hline
\end{tabular}




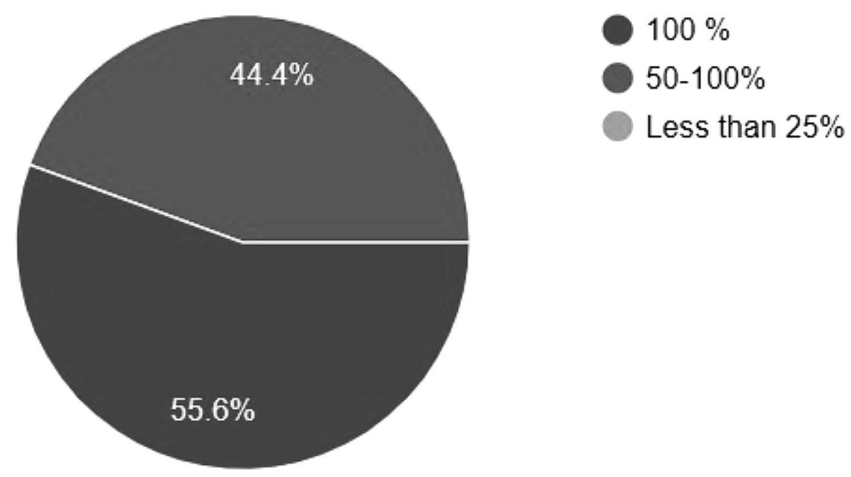

Figure 1. Showing the results of percentage of employees working remotely

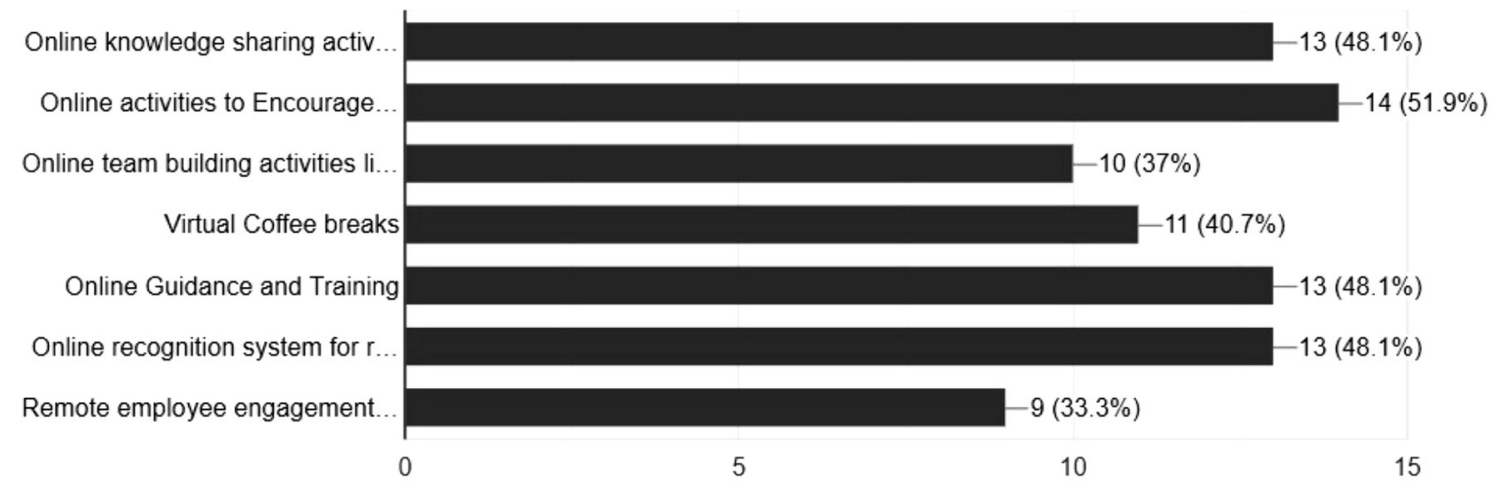

Figure 2. Showing the results of recent practices currently adopted

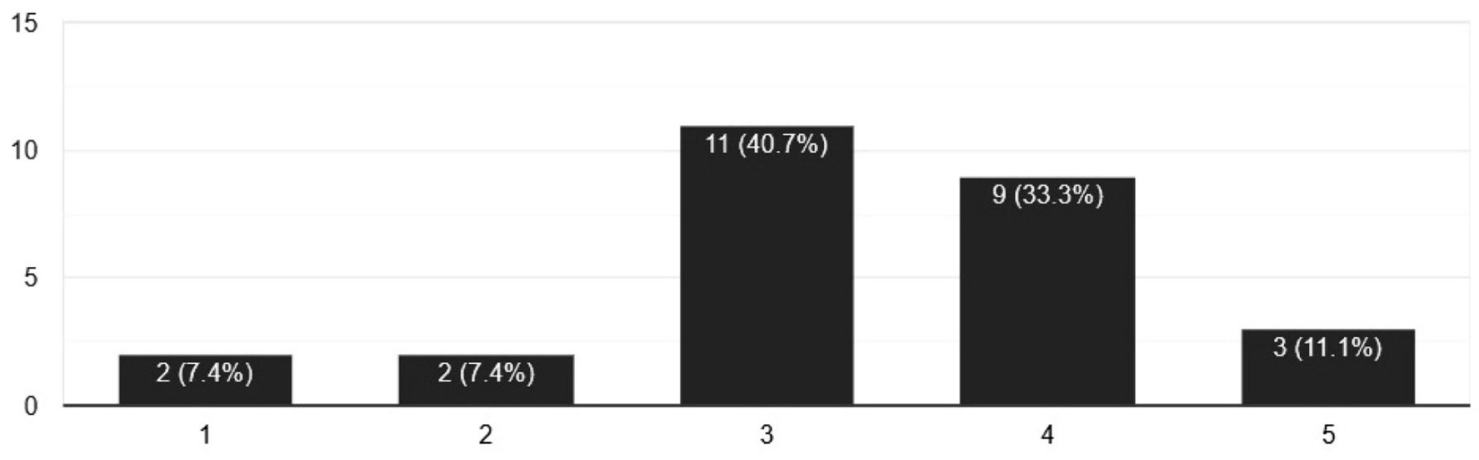

Figure 3. Showing the results of engagement level on a scale of 1-5

Interpretation of Figure 1: We can infer from the chart figure 1 that Most Organizations have transitioned to 50 percent of Employees working Remotely - With 55.6 percent of the respondent organizations having shifted to a $100 \%$ Remote working pattern.

Interpretation of Figure 2: From the chart figure 2, it can be observed that the most common practise adopted in majority of the organisations surveyed is "Online activities to Encourage Health and Wellness" closely followed by "Online knowledge sharing activities" and "Online guidance and training and online recognition system" - thereby comprehensively supporting the remote worker.

Interpretation of Figure 3: From the above graph figure 3 , it can be observed that 40.7 percent 


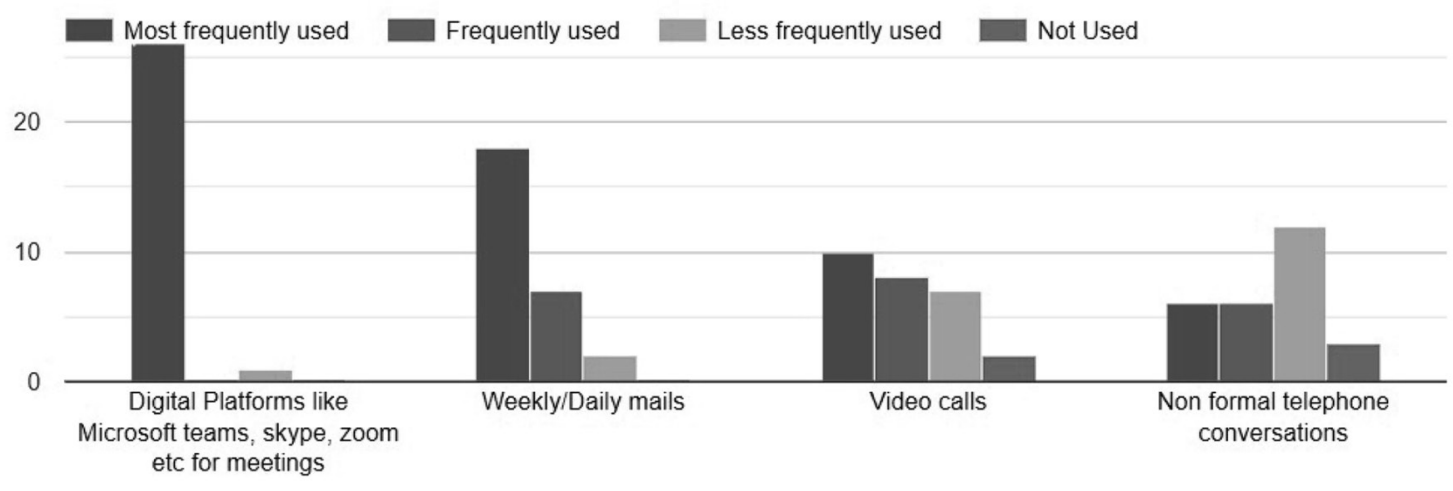

Figure 4. Showing the results of frequency of communication channels used for engaging the employees remotely

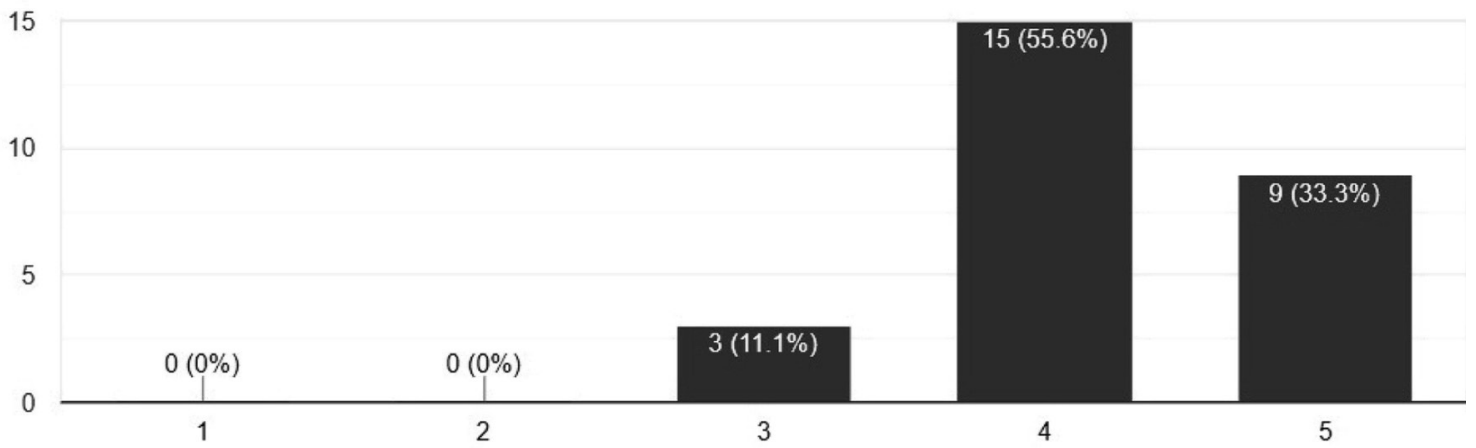

Figure 5. Showing the results of Productivity level after a year of Remote working on a scale of 1-5

of respondents claim that engagement level in their Organisation is 3 on a scale of 5 while 11.1 percent of experts say that the level of employee engagement is highest i.e., 5. A very low percentage of respondents believe that the Engagement level is on the lower end of the scale.

Interpretation of Figure 4: From the figure 4 it can be interpreted that, the most frequently used communication channels used for engaging employees are digital platforms like Microsoft teams, skype, zoom for meetings followed by weekly/daily mails.

Interpretation of Figure 5: From the above graph figure 5 , it can be inferred that the productivity level of the organization after a year of remote working on a scale of 1-5 is at least 4 for 55.6 percent of $\mathrm{HR} /$ people managers who responded to the Survey whereas only a few i.e. 11.1 percent say it is 3. Essentially the remote working has not really impacted Productivity per se. 


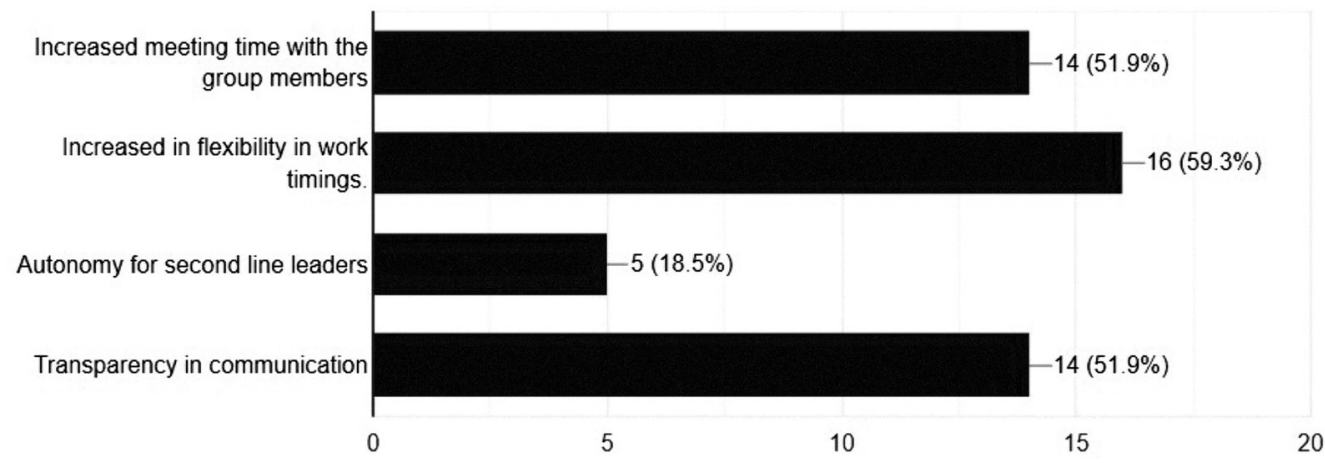

Figure 6. Showing results of changes/practices adopted by leaders in your organisation to maintain the Engagement level of Remote workers

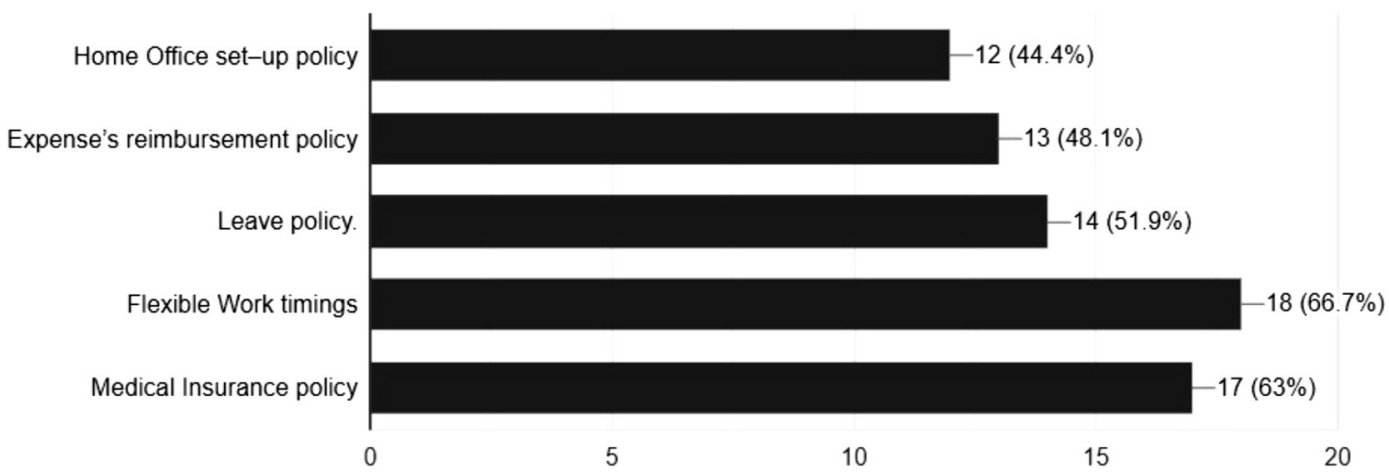

Figure 7. Showing the results the policy changes the organization has enabled remote working during the Covid-19 Pandemic situation

Interpretation of Figure 7: From the above graph figure 7 , it can be inferred that the policy changes made by the organisation to enable remote working during the Covid-19 Pandemic situation is Medical Insurance policy, Flexible work timings and changes in leave policy - these three factors are found to be providing the fundamental drivers enabling Remote working.

\section{MANAGERIAL IMPLICATIONS}

There have been significant studies and publications that have analyzed and detailed the remote working scenario, this paper has attempted to aggregate best practices and policies that would have a positive and favorable impact on employee engagement based on the secondary data as described above.
Further to the analysis from the secondary literature, a survey tool was administered as a part of this papers' primary data collection strategy. Presented in this paper is the analysis and inferences based on the survey responses. A summary view of the primary data analysis reveals close alignment of employee engagement practices with the productivity outcomes of the employee in their respective organizations as noted in the analysis, we also found a high degree of consistency between the secondary literature analysis and the survey tool output.

\section{CONCLUSION}

To conclude this paper has proposed through its inferences the best practices and policies which when employed by the organization would lead to 
an increase in employee engagement and thereby productivity. This paper is proposed to be used as a reference and there is tremendous scope for a deep dive analysis of enablers that drive engagement as put down by the primary data collection tool. Our sincere gratitude and appreciation to all the authors and publications for providing a good insight on the topic of the theme of this paper and providing us a good secondary data collection to reference.

\section{REFERENCES}

Chanana, N., \& Sangeeta. (2020). Employee engagement practices during Covid-19lockdown. Journal of Public Affairs, September. https://doi.org/10.1002/pa.2508

Chandani, A., Mehta, M., Mall, A., \& Khokhar, V. (2016). Employee engagement: A review paper on factors affecting employee engagement. Indian Journal of Science and Technology, 9(15). https://doi.org/10.17485/ijst/2016/v9i15/92145

Dixit, A. R., \& Singh, S. (2020). Understanding drivers of engagement from employee's perspective during COVID-19. International Journal of Management, 11(10), 943-959. https://doi.org/10.34218/IJM.11.10.2020.087

Gaurav, J. (2020). Draw Closer To Your Employees in Times of Social Distancing: Suggestive Framework for Employee Engagement During Lockdown Due To (Covid-19) https://doi.org/10.13140/RG.2.2.22377.31849

Hrmagazine, K., \& Winter, A. (2020). Measuring Employee Engagement During a Crisis. Winter, 1-6.

Kumar, A., \& Kapoor, S. (2020). Employee Engagement Amidst Covid-19 pandemic: A Challenge or Opportunity for Indian Organisations. International Journal of Advanced Science and Technology, 29(9 Special Issue), 1980-1987. https:// www.scopus.com/inward/record.uri?eid=2-s2.0-85085104276\&partnerID=40\&md5=3c5887b5b4d90d72008917b39f0 bbe 22

Pattnaik, L., \& Jena, L. K. (2020). Mindfulness, remote engagement, and employee morale: conceptual analysis to address the "new normal." International Journal of Organizational Analysis. https://doi.org/10.1108/IJOA-06-2020-2267

Saji, B. S. (2014). Employee Engagement and Its Role during Crisis Management: A Conceptual Model. European Journal of Business and Management, 6(19), 110-117. http://iiste.org/Journals/index.php/EJBM/article/view/13730

Yadav, S., Dubey, A., Chawla, P., \& Abvsme, J. (2020). Employee Engagement Strategy for Employees Working in Virtual Environment in the IT Industry. 03, 1-11. 